\title{
AJARAN MORAL DAN KARAKTER DALAM FABEL KISAH DARI NEGERI DONGENG KARYA MULASIH TARY (KAJIAN SASTRA ANAK SEBAGAI BAHAN AJAR DI SEKOLAH DASAR)
}

\author{
M. Ridwan \\ ridwan_esto@yahoo.co.id \\ PGSD STKIP PGRI Sumenep
}

\begin{abstract}
The crisis of moral and character are serious talk and continuously. Indonesia has problem in moral and character crisis. Last month and also latest few years aggressively presented how the moral destruction of children, for example: sexual harassment and sexual abuse happen everywhere. In fact, the fate of the nation depends on them. Children are a golden generation that will continue struggle of the founders of this nation. That fact becomes our responsible, not just the government, teachers and parents and the environment. All citizens must intervene to face both moral and character emergency. Therefore, children's literature comes to a repair process and the moral character of the nation. Children's literature should be re-presented and enjoyed by them. The purposes of the study are: 1) describe a study of moral teachings and character found in fable The Tale of Tales of State and, 2) recommends that children's literature can be interesting and fun for teaching materials.

Keywords: Moral Teachings and Character, Fable, Literature and Teaching Materials
\end{abstract}

\begin{abstract}
ABSTRAK
Masalah krisis moral dan karakter adalah perbincangan yang serius dan terus menerus. Bangsa Indonesia krisis moral dan karakter yang luar biasa. Beberapa tahun bahkan bulan terakhir gencar disuguhkan bagaimana hancurnya moral anakanak, mulai dari pelecehan seksual dan pencabulan di mana-mana, padahal nasib bangsa ini bergantung kepada mereka. Anak adalah generasi emas yang akan melanjutkan proses perjuangan para pendiri bangsa ini. Fakta tersebut adalah tanggung jawab bersama, bukan semata pemerintah, guru dan orang tua dan lingkungan. Semua harus turun tangan menghadapi darurat moral dan karakter ini. Oleh Karena itu, sastra anak hadir untuk sebuah proses memperbaiki moral dan karakter anak bangsa. Sastra anak harus kembali disuguhkan dan dinikmati oleh mereka. Tujuan dari penelitian 1) mendeskripsika kajian terhadap ajaran moral dan karakter yang teradapat dalam fabel Kisah dari Negeri Dongeng dan, 2) merekomendasi sastra anak untuk menjadi bahan ajar sebagai sarana hiburan yang menyenangkan.

Kata Kunci: Ajaran Moral dan Karakter, Fabel, Sastra Anak dan Bahan Ajar.
\end{abstract}




\section{A. PENDAhuluan}

Sastra selain sebagai karya yang cerdas, kreatif, imajinatif, juga memiliki susunan nilai kearifan dan ajaran tentang moral dan karakter. Ajaran dan nilai kearifan di sini adalah nilai guna dan nilai estetika yang memikat bagi penikmatnya. Burhan (2013:2) menyatakan bahwa sastra berbicara tentang hidup dan kehidupan, tentang berbagai persoalan hidup manusia, tentang kehidupan di sekitar manusia, tentang kehidupan pada umumnya, yaitu diungkapkan dengan cara dan bahasa yang khas. Bahasa sastra lebih bernuansa keindahan daripada kepraktisan. Karakteristik tersebut juga berlaku dalam sastra anak.

\section{Sarumpaet (2007:}

menyatakan bahwa pembelajaran sastra hendaknya mempertimbangkan keseimbangan pengembangan pribadi dan kecerdasan peserta didik. Pembelajaran semacam ini akan mempertimbangkan keseimbangan antara spiritual, emosional, etika, logika, estetika dan kinestetika. Hal wajib diingat dalam jenjang Sekolah Dasar adalah pentingnya memperkenalkan sebanyak mungkin variasi dan jenis karya sastra, lalu membaca dan menikmatinya. Para ahli psikologi menyatakan anak SD sudah memiliki kemampuan kognitif yang memampukannya bernalar (walau semula masih bersifat induktif), bisa mengingat, mampu menggunakan kalimat yang semakin kompleks dan semakin sosial.

Peran sastra anak dalam kehidupan mereka tentunya memiliki porsi yang cukup besar, karena dengan sastra anak baik melalui proses membaca sendiri atau menyimak cerita yang dibacakan oleh orang lain adalah kegiatan yang menyenangkan dan menjadi sarana hiburan. Karya sastra anak diyakini dapat digunakan sebagai alat yang sangat efektif bagi para pendidik maupun para orang tua di dalam menanamkan nilai-nilai, norma, perilaku luhur, dan kepercayaan yang di dalam suatu masyarakat atau budaya (Ikhwan, 2013:71). Penanaman nilai moral terhadap anak-anak khususnya melalui internalisasi pengetahuan kesusastraan anak mengalami kemunduran yang bertubi-tubi sehingga berdampak pada moral anak yang kering dan brutal, 
jauh dari apa menjadi harapan orang tua dan bangsa.

Definisi dari fabel sendiri adalah cerita binatang yang dimaksudkan sebagai personifikasi karakter manusia. Binatang-binatang yang dijadikan tokoh cerita dapat berbicara, bersikap, dan berperilaku sebagaimana halnya manusia. Pada umumnya fabel tidak panjang dan secara jelas mengandung ajaran moral, dan pesan moral itu secara nyata biasanya ditempatkan pada bagian akhir cerita. Tujuan penyampaian dan atau ajaran moral inilah yang menjadi fokus penceritaan dan sekaligus yang menyebabkan hadirnya fabel di tengah masyarakat (Nurgiyantoro, 2013: 23).

Sayangnya, sastra anak dewasa ini cenderung diabaikan, padahal sastra anak sudah sepatutnya dikonsumsi oleh anak-anak sejak mulai baru belajar berbicara dan menyimak hingga usia sekolah dasar. Salah satu fakta anak-anak kurang tertarik terhadap sastra anak berbentuk fabel, dongeng dan puisi-puisi anak karena mereka lebih memilih dan menikmati tontonan serial anak semisal Masha, IpinUpin, Boboy Boy atau bentuk-bentuk bacaan lain berupa komik bergambar dari Jepang yang dalam pemahaman mereka lebih menantang dan mengasyikkan.

Oleh karena itu, kajian dan analisis terhadap karya sastra anak kemudian diimplementasikan dalam proses pembelajaran di sekolah dasar, dan diformulasi menjadi bahan ajar dari karya yang mengandung nilainilai moral bisa dipastikan mengubah paradigma sebagian anak tentang sastra yang selama ini dipandang kaku, kurang menyenangkan dan tidak menarik. Fokus kajian sastra anak dalam penelitian ini adalah ketajaman analisis terhadap buku teks tentang ajaran moral dan karakter dalam buku kumpulan cerita fabel berjudul Kisah Dari Negeri Dongeng Karya Mulasih Tary, seorang Mahasiswa Pascasarjana Universitas Muhammadiyah Purwokerto dan saat ini mengabdikan diri sebagai Guru di Puwokerto. Tujuan penelitian ini untuk mendeskripsikan ajaran moral dan karakter yang terdapat dalam cerita fabel Kisah Dari Negeri Dongeng melalui kajian dan analisis yang matang serta mewujudkan sastra anak menjadi bahan ajar sebagai solusi 
kesenjangan moral dan karakter anak di sekolah dasar.

\section{B. METODE PENELITIAN}

Penelitian ini dirancang dengan model deskriptif kualitatif. Rancangan kualitatif deskriptif merupakan rancangan penelitian untuk menganalisis dan menyajikan fakta berupa data dimensi ajaran moral dalam Fabel Kisah Dari Negeri Dongeng, untuk dideskripsikan dengan menggunakan interpretasi yang sifatnya kualitatif. Penelitian ini menggunakan metode deskriptif kualitatif, yaitu suatu metode yang berusaha menggambarkan secara sistematis, fakta-fakta dan ciri-ciri data berupa ajaran moral yang dianalisis, dengan menggunakan pendekatan deskriptif-analitik.

Penggunaan metode deskriptif dan beberapa pendekatan ini karena dipandang sesuai dengan masalah dan tujuan penelitian yang telah ditentukan serta berusaha mendeskripsikan sejumlah kegelisahan masyarakat tentang krisisnya moral anak-anak usia sekolah dasar dan perlunya implementasi ajaran moral yang dihasilkan dari kajian dalam Fabel Kisah Dari Negeri Dongeng karya Mulasih Tary. Di sisi lain, hal tersebut didasari pula oleh dua pertimbangan pokok yaitu dari karakteristik dan segi tujuan yang ingin dicapai dalam penggunaan metode kualitatif deskriptif.

$$
\text { Penelitian menggunakan }
$$
beberapa tahap, yaitu mulai dari pengumpulan data, analisis data dan penyimpulan. Sumber data dalam penelitian ini adalah Fabel Kisah Dari Negeri Dongeng karya Mulasih Tary. Buku ini diterbitkan tahun 2013 oleh Penerbit Pustaka Anak di Yogyakarta. Fabel Kisah Dari Negeri Dongeng berisi 8 cerita tentang binatang yang lucu-lucu, di antaranya: 1. Lampu Kunang-Kunang; $2 . \quad$ Tubuh Kelelawar; 3. Kelinci dan Laba; 4. Kemenangan Penghuni Hutan; 5. Kiko Semut, Tak mau Berjabat Tangan; 6. Kisah Nasi Menangis; 7. Mutiara Nera Kerang; 8. Negeri Kejujuran. 


\section{HASIL PENELITIAN}

Tabel. Deskripsi Ajaran Moral dan Karakter

\begin{tabular}{|c|c|c|c|}
\hline No & Judul & Deskripsi Ajaran Moral dan Karakter & Kodifikasi \\
\hline 1 & $\begin{array}{l}\text { Lampu } \\
\text { Kunang- } \\
\text { kunang }\end{array}$ & $\begin{array}{l}\text { "Terimakasih kalian sudah membantu } \\
\text { kami melawan ketakutan pada malam hari," } \\
\text { semua penghuni hutan mengucapkan } \\
\text { terimakasih kepada keluarga Kunang- } \\
\text { kunang. } \\
\text { "Bagaimana Rin, apakah kau masih } \\
\text { menganggap kalau kau ini binatang yang } \\
\text { tidak berguna?" senyum Rin mengembang } \\
\text { dengan pertanyaan Ibunya, ternyata benar } \\
\text { apa yang dikatakan Ibunya selama ini, Rin } \\
\text { adalah binantang terlampau istimewa. }\end{array}$ & $\begin{array}{l}\text { \#moral } \\
\text { \#karakter } \\
\text { \#lampu } \\
\text { kunang- } \\
\text { kunang }\end{array}$ \\
\hline 2 & $\begin{array}{l}\text { Tubuh } \\
\text { Kelelawar }\end{array}$ & $\begin{array}{l}\text { "Kalian dengar baik semua penghuni hutan } \\
\text { penghuni hutan, bahwasanya pada hari ini } \\
\text { saya memutuskan dengan banyak } \\
\text { pertimbangan. Saya memutuskan kalau } \\
\text { kelelawar itu memiliki dua jenis, jadi bagi } \\
\text { kalian para tikus dan burung janganlah } \\
\text { kalian selalu meremehkan kelelawar karena } \\
\text { mulai hari ini para kelelawar mendapatkan } \\
\text { keistimewaan yaitu binatang yang memiliki } \\
\text { dua jenis yaitu jenis burung dan tikus. } \\
\text { Keputusan saya tidak bisa diganggu gugat. } \\
\text { Begitulah si raja hutan menyelesaikan } \\
\text { masalah kelelawar, dan mulai saat itu para } \\
\text { kelelawar tidak dihina lagi karena } \\
\text { statusnya. Justru kelelawar menjadi sangat } \\
\text { dihormati oleh teman-temannya. }\end{array}$ & $\begin{array}{l}\text { \#moral } \\
\text { \#karakter } \\
\text { \#tubuh } \\
\text { kelelawar }\end{array}$ \\
\hline 3 & $\begin{array}{l}\text { Kelinci dan } \\
\text { Laba-laba }\end{array}$ & $\begin{array}{l}\text { Kali ini kelinci mengerti, kalau Laba-laba } \\
\text { sangat curang. Ia ingin member pelajaran } \\
\text { kepada Laba-laba. } \\
\text { "Baiklah, kau bisa menemukan madu yang } \\
\text { manis di atas pohon rindang itu," tunjuk } \\
\text { Kelinci. } \\
\text { Tanpa berpikir panjang Laba-laba rakus itu } \\
\text { langsung naik ke atas pohon. Alangkah } \\
\text { terkejutnya Laba-laba ketika mulai } \\
\text { mengambil madu tersebut. Ratusan lebah } \\
\text { menyengat tubuhnya. } \\
\text { "Aoooow, tolong aku Kelinci, } \\
\text { sakit..ampun...," teriak Laba-laba. Tetapi }\end{array}$ & $\begin{array}{l}\text { \#moral } \\
\text { \#karakter } \\
\text { \#kelinci dan } \\
\text { laba-laba }\end{array}$ \\
\hline
\end{tabular}




\begin{tabular}{|c|c|c|c|}
\hline No & Judul & Deskripsi Ajaran Moral dan Karakter & Kodifikasi \\
\hline & & $\begin{array}{l}\text { kelinci sudah pergi dari tempat itu dan ia tak } \\
\text { mau lagi berteman dengan laba-laba. }\end{array}$ & \\
\hline 4 & $\begin{array}{l}\text { Kemenangan } \\
\text { Penghuni } \\
\text { Hutan }\end{array}$ & $\begin{array}{l}\text { Mereka lalu beriringan menuju tenda para } \\
\text { penebang pohon. Tugas pertama dilakukan } \\
\text { oleh Ular. Mereka menyusup ke tenda- } \\
\text { tenda para penebang pohon tersebut, para } \\
\text { penebang kocar-kacir ketakutan } \\
\text { mengetahui banyak ular yang masuk ke } \\
\text { tenda mereka. Lalu pasukan gajah yang } \\
\text { memang sudah berada di depan tenda. } \\
\text { Pasukan gajah langsung masuk ke dalam } \\
\text { tenda, untuk memastikan keadaan. Para } \\
\text { penebang pohon sudah keluar semua, } \\
\text { mereka akan mengambil senjata. Kini } \\
\text { giliran pasukan semut yang menyerang. } \\
\text { Sebelum para penebang pohon mebidikkan } \\
\text { senjata-senjatanya pasukan semut sudah } \\
\text { terlebih dahulu menggigit kaki mereka. } \\
\text { Kini pera penebang pohon liar itu semakin } \\
\text { ketakutan. Mereka berlari tidak karuan di } \\
\text { dalam gelapnya malam. Tetapi pasukan } \\
\text { singa serta pasukan macan mengejarnya. } \\
\text { Sampai akhirnya para penebang pohon lari } \\
\text { dan tidak kembali lagi. }\end{array}$ & $\begin{array}{l}\text { \#moral } \\
\text { \#karakter } \\
\text { \#kemenang } \\
\text { an penghuni } \\
\text { hutan }\end{array}$ \\
\hline 5 & $\begin{array}{l}\text { Kiko Semut, } \\
\text { Tak Mau } \\
\text { Berjabat } \\
\text { Tangan }\end{array}$ & $\begin{array}{l}\text { Kini Kiko sangat senang, karena bisa } \\
\text { berkumpul lagi dengan teman-temannya, } \\
\text { yang selama ini mengira Kiko berubah, } \\
\text { ternyata itu hanya salah paham, dan } \\
\text { ternyata kesalah pahaman bisa merusak } \\
\text { persahabatan. }\end{array}$ & $\begin{array}{l}\text { \#moral } \\
\text { \#karakter } \\
\text { \#kiko semut }\end{array}$ \\
\hline 6 & $\begin{array}{l}\text { Kisah Nasi } \\
\text { Menangis }\end{array}$ & $\begin{array}{l}\text { "Aku akan memaafkanmu tetapi kamu } \\
\text { harus berjanji tidak akan menyisakan } \\
\text { makanan yang sedang kamu makan, dan } \\
\text { tidak akan membuang-buang makanan } \\
\text { lagi," Nasi membuat kesepakatan dengan } \\
\text { Noe. } \\
\text { Noe pun berjanji Ia akan selalu } \\
\text { menghabiskan makanannya dan tidak akan } \\
\text { membuang-buangnya lagi. }\end{array}$ & $\begin{array}{l}\text { \#moral } \\
\text { \#karakter } \\
\text { \#kisah nasi } \\
\text { menangis }\end{array}$ \\
\hline 7 & $\begin{array}{l}\text { Mutiara Nera } \\
\text { Kerang }\end{array}$ & $\begin{array}{l}\text { "Wah, indah sekali kalungnya. Kau yang } \\
\text { membuatkannya untukku?" Tanya Puteri } \\
\text { Febe. }\end{array}$ & $\begin{array}{l}\text { \#moral } \\
\text { \#karakter } \\
\text { \#mutiara } \\
\text { nera kerang }\end{array}$ \\
\hline
\end{tabular}




\begin{tabular}{|c|c|c|c|}
\hline No & Judul & Deskripsi Ajaran Moral dan Karakter & Kodifikasi \\
\hline & & $\begin{array}{l}\text { "Bukan aku yang membuat tetapi Ibuku. } \\
\text { Dan itu dari airmataku puteri," Nera Kerang } \\
\text { tersenyum sambil memberikan penjelasan. } \\
\text { // } \\
\text { Usai pesta Puteri Febe Ikan memberikan } \\
\text { sebuah penghargaan kepada Nera Kerang. } \\
\text { Puteri Febe meminta Nera Kerang dan } \\
\text { Ibunya tinggal di kerajaan laut. Nera } \\
\text { Kerang sangat senang mendapat tawaran } \\
\text { tersebut. Itu artinya Ia akan memiliki teman } \\
\text { yaitu Puteri Febe Ikan yang sangat baik hati. } \\
\text { Kuku Kura-kura dan Muo Ikan pun } \\
\text { meminta maaf karena selama ini telah } \\
\text { meremehkan Nera. }\end{array}$ & \\
\hline 8 & $\begin{array}{l}\text { Negeri } \\
\text { Kejujuran }\end{array}$ & $\begin{array}{l}\text { Mafi adalah seekor kelinci yang sangat lucu } \\
\text { dan lincah tetapi hari ini Ia tidak seperti } \\
\text { biasanya yang selalu lucu dan lincah. Ia } \\
\text { terlihat seperti sedang bingung dan sedih } \\
\text { karena keinganannya sela ini belum } \\
\text { terpenuhi. Dia sangat menginginkan sepeda } \\
\text { seperti teman-temannya. } \\
\text { // } \\
\text { "Apa kamu yakin tidak akan dibelikan } \\
\text { sepeda oleh Papa-Mamamu?" kata Suara } \\
\text { yang mengagetkan Mafi, yang ternyata } \\
\text { adalah Peri Mawar yang keluar dari salah } \\
\text { satu bunga mawar yan di tanam oleh mama. } \\
\text { "Aku sangat yakin Peri," kata Mafi sedih. } \\
\text { "Aku ada saran, bagaimana kalau kamu aku } \\
\text { ajak ke Negeri kejujuran?" kata Peri } \\
\text { Mawar. } \\
\text { // "Negeri kejujuran yang berada dalam } \\
\text { hatimu," jawab Peri Mawar dengan } \\
\text { senyumnya yang merekah seperti bungan } \\
\text { mawar. } \\
\text { // "Begini Mafi, sekarang kamu temui Papa } \\
\text { dan Mamamu, lalu kamu pejamkan matamu } \\
\text { dan kamu katakan apa yang ada dalam } \\
\text { hatimu, itu berarti kamu sudah memasuki } \\
\text { Negeri Kejujuran," Kata Peri Mawar } \\
\text { menjelaskan. } \\
\text { // }\end{array}$ & $\begin{array}{l}\text { \#moral } \\
\text { \#karakter } \\
\text { \#negeri } \\
\text { kejujuran }\end{array}$ \\
\hline
\end{tabular}




\begin{tabular}{|c|c|c|c|}
\hline No & Judul & Deskripsi Ajaran Moral dan Karakter & Kodifikasi \\
\hline & & $\begin{array}{l}\text { Mafi langsung bergegas menemui Papa- } \\
\text { Mamanya yang sedang asyik } \\
\text { bercengkrama. } \\
\text { "Ada apa Mafi, kok muka kamu di tekuk } \\
\text { kaya gitu?" Tanya Papa meledek Mafi. } \\
\text { Mafi mulai memejamkan matanya dan dia } \\
\text { mulai memasuki Negeri Kejujuran yang ada } \\
\text { di hatinya, Papa menggeleng-gelengkan } \\
\text { kepalanya melihat anaknya yang } \\
\text { kelakuannya aneh. } \\
\text { "Papa-Mama, Mafi boleh meminta sepeda } \\
\text { untuk pergi ke sekolah tidak, soalnya Mafi } \\
\text { sering terlambat ke sekolah, bahkan kadang } \\
\text { sesampai di kelas Mafi tidak mengikuti } \\
\text { pelajaran dengan baik karena terlalu lelah } \\
\text { dan capek akibat jalan terlalu jauh," kata } \\
\text { Mafi masih memejamkan ke dua matanya. } \\
\text { Kali ini Papa-Mama malah tersenyum } \\
\text { melihat tingkah laku Mafi yang lucu. } \\
\text { "Ya sayang besok Papa belikan, kebetulan } \\
\text { hari ini Papa baru dapat rejeki jadi bisa } \\
\text { langsung membelikan sepeda untukmu," } \\
\text { kata Papa. } \\
\text { // } \\
\text { "Terimakasih Peri Mawar, ternyata pergi ke } \\
\text { Negeri kejujuran itu menyenangkan," kata } \\
\text { Mafi. } \\
\text { // } \\
\text { Mulai besok aku akan bisa bersepeda ke } \\
\text { sekolah, terima kasih Papa-Mama dan juga } \\
\text { Peri Mawar yang mengajakku pergi ke } \\
\text { Negeri Kejujuran," kata } \\
\text { mengembangkan senyumnya. }\end{array}$ & \\
\hline
\end{tabular}

\section{PEMBAHASAN}

Disadari atau tidak, sastra anak memiliki kontribusi yang besar bagi perkembangan kepribadian anak dalam proses menuju ke dewasaan sebagai manusia yang mempunyai jati diri yang jelas. Penanaman nilai-nilai dapat dilakukan sejak anak masih belum dapat berbicara dan belum dapat membaca. Nyanyian-nyanyian yang biasa didendangkan seorang ibu untuk membujuk agar si buah hati 
segera tertidur atau sekedar untuk menyenangkan, pada hakikatnya juga bernilai kesastraan dan sekaligus mengandung nilai yang besar andilnya bagi perkembangan kejiwaan anak, misalnya nilai kasih saying dan keindahan (Nurgiyantoro, 2013: 3536). Realitas tersebut banyak ditemukan dalam sastra anak baik yang berbentuk cerita anak, novel anak dan cerita binatang atau fabel. Pembahasan dari hasil penelitian ini mengkaji beberapa aspek penting yang terdapat dalam cerita fabel Kisah dari Negeri Dongeng dalam perspektif ajaran moral dan karakter untuk menjadi bahan ajar dalam proses pembelajaran bagi anak-anak.

1. Ajaran Moral dan Karakter dalam Fabel Kisah dari Negeri Dongeng Koesoema

$(2007: 118)$

menyatakan pendidikan karakter mengemban dua tugas, yaitu mengembangkan kemampuan dan mengembangkan kemampuan moral. Ajaran moral dan penanaman karakter menjadi penting diimplementasi sejak usia anak-anak. Bangsa Indonesia berada di titik darurat moral dan krisis karakter. Moral dan karkter anak sungguh memprihatinkan akhir-akhir ini ketika di mana-mana terjadi pelecehan seksual dan pencabulan, pelaku dan korbannya kebanyakan dari kalangan anak-anak. Pentingnya menyalurkan pengetahuan tentang sastra anak yang kaya ajaran moral dan karakter sudah menjadi keharusan orang tua dan para guru di sekolah dasar untuk kembali dituturkan dan diajarkan. Ajaran moral tentang seberapa besar manfaat sebagai mahkluk di muka bumi untuk masyarakat sekitar dapat disimak dalam Fabel Lampu Kunang-kunang yang telah mengajari anak-anak untuk saling mendukung, membantu dan memaafkan.

"Terimakasih kalian sudah membantu kami melawan ketakutan pada malam hari," semua penghuni hutan mengucapkan terimakasih kepada keluarga Kunang-kunang.

"Bagaimana Rin, apakah kau masih menganggap kalau kau ini binatang yang tidak berguna?" senyum Rin mengembang dengan pertanyaan Ibunya, ternyata benar apa yang dikatakan Ibunya selama ini, Rin adalah binantang terlampau istimewa. \#moral \#karakter \#lampu kunangkunang \#04 
Moral dan karakter seorang pemimpin derajatnya harus selalu menjunjung tinggi keadilan yang nyata terhadap seluruh kepentingan rakyatnya dan menjadi solusi dari segala macam masalah. Dalam cerita fabel berjudul Tubuh Kelelawar begitu sederhana dinarasikan bagaimana pemimpin harus adil dan tegas dalam mengambil keputusan. Semoga para pemimpin mampu belajar dari fabel moral para binatang.

"Kalian dengar baik semua penghuni hutan penghuni hutan, bahwasanya pada hari ini saya memutuskan dengan banyak pertimbangan. Saya memutuskan kalau kelelawar itu memiliki dua jenis, jadi bagi kalian para tikus dan burung janganlah kalian selalu meremehkan kelelawar karena mulai hari ini para kelelawar mendapatkan keistimewaan yaitu binatang yang memiliki dua jenis yaitu jenis burung dan tikus. Keputusan saya tidak bisa diganggu gugat.

Begitulah si raja hutan menyelesaikan masalah kelelawar, dan mulai saat itu para kelelawar tidak dihina lagi karena statusnya. Justru kelelawar menjadi sangat dihormati oleh teman- temannya. \#moral \#karakter \#tubuh kelelawar \#07

Dalam situasi apapun, menjadi culas, curang, picik, dan licik tidak pernah dibenarkan. Begitulah cerita Kelinci dan Laba-laba yang bercerita perihal kepicikan dan kecurangan si Laba-laba kepada Kelinci, sahabatnya sendiri. Pada waktunya, yang curang akan masuk ke jurang tanpa ampun.

Kali ini kelinci mengerti, kalau Labalaba sangat curang. Ia ingin member pelajaran kepada Laba-laba.

"Baiklah, kau bisa menemukan madu yang manis di atas pohon rindang itu, " tunjuk Kelinci.

Tanpa berpikir panjang Laba-laba rakus itu langsung naik ke atas pohon. Alangkah terkejutnya Laba-laba ketika mulai mengambil madu tersebut. Ratusan lebah menyengat tubuhnya.

"Aoooow, tolong aku Kelinci, sakit..ampun...," teriak Laba-laba. Tetapi kelinci sudah pergi dari tempat itu dan ia tak mau lagi berteman dengan laba-laba. \#moral \#karakter \#kelinci dan laba-laba \#11

Hal tersebut menjadi penting bahwa ajaran moral dan pendidikan karakter merupakan wahana 
sosialisasi karakter-karakter yang ke tenda mereka. Lalu pasukan gajah patut dimiliki oleh seorang anak yang memang sudah berada di depan sebagai sarana pembentukan generasi tenda. Pasukan gajah langsung masuk yang banyak memberikan manfaat ke dalam tenda, untuk memastikan untuk lingkungan sekitarnya. keadaan. Para penebang pohon sudah (Kusmarwanti, 2012).

Membaca cerita Kemenangan Penghuni Hutan mengingatkan pada fakta pembalakan dan penebangan liar hutan di daerah Sumatera dan Kalimantan oleh monster-monster yang tidak bertanggung jawab. Akibat dari ulah tangan manusia yang rakus dan serakah, binatang di hutan dan dampak lingkungan terhadap manusia semakin menderita. Sekali waktu, sesuai dengan ajaran moral dari cerita, semua penghuni hutan harus kompak dan menyusun strategi bersama untuk member pelajaran kepada manusia yang rakus dan serakah tersebut. Semuanya harus harus bersatu demi kelangsungan kehidupan berbangsa dan bernegara yang aman sentosa.

Mereka lalu beriringan menuju tenda para penebang pohon. Tugas pertama dilakukan oleh Ular. Mereka menyusup ke tenda-tenda para penebang pohon tersebut, para penebang kocar-kacir ketakutan mengetahui banyak ular yang masuk keluar semua, mereka akan mengambil senjata. Kini giliran pasukan semut yang menyerang. Sebelum para penebang pohon mebidikkan senjata-senjatanya pasukan semut sudah terlebih dahulu menggigit kaki mereka. Kini pera penebang pohon liar itu semakin ketakutan. Mereka berlari tidak karuan di dalam gelapnya malam. Tetapi pasukan singa serta pasukan macan mengejarnya. Sampai akhirnya para penebang pohon lari dan tidak kembali lagi. \#moral \#karakter \#kemenangan penghuni hutan \#15_16 Tidak ada yang lebih menyenangkan daripada hidup rukun, jauh dari salah paham, berjabat tangan dan menjalin serta berkumpul dalam keakraban dengan para sahabat. Semua bisa dinikmati dalam cerita Kiko Semut, tak Mau berjabat Tangan yang penuh dengan persahabatan dan suka cita.

Kini Kiko sangat senang, karena bisa berkumpul lagi dengan teman- 
106 | Premiere Educandum, Volume 6 Nomor 1, Juni 2016, 95 - 109

temannya, yang selama ini mengira Kiko berubah, ternyata itu hanya salah paham, dan ternyata kesalah pahaman bisa merusak persahabatan. \#moral \#karakter \#kiko semut tak mau berjabat tangan \#20

Di tengah arus modernisasi dan globalisasi yang sengit kemajuannya, terkadang manusia cenderung abai terhadap rejeki yang menjadi makanan pokok untuk hidup sehari-hari. Pemerintah menggalakkan program bagaimana di sektor pangan Indonesia mampu bertahan dan mengutuk impor bahan-bahan pokok yang bisa dicari di negeri sendiri. Pelajaran dari Kisah Nasi Menangis adalah tamparan halus terhadap realitas kemanusiaan yang bisa ditemui di banyak tempat tentang hidup foya-foya dan buang-buang makanan, jauh dari hidup sederhana.

“Aku akan memaafkanmu tetapi kamu harus berjanji tidak akan menyisakan makanan yang sedang kamu makan, dan tidak akan membuang-buang makanan lagi," Nasi membuat kesepakatan dengan Noe.

Noe pun berjanji Ia akan selalu menghabiskan makanannya dan tidak akan membuang-buangnya lagi. \#moral \#karakter \#kisahnasimenagis \#23

Setiap makhluk ciptaan Tuhan pasti memiliki keistimewaan dan kekurangan. Semuanya seharusnya saling melengkapi menuju kesempurnaan bersama. Begitulah ajaran dan pesan moral serta karakter dari cerita Mutiara Nera Kerang yang membuat ruang kesadapan manusia terbuka, bahwa semuanya tidak ada yang sempurna.

Usai pesta Puteri Febe Ikan memberikan sebuah penghargaan kepada Nera Kerang. Puteri Febe meminta Nera Kerang dan Ibunya tinggal di kerajaan laut. Nera Kerang sangat senang mendapat tawaran tersebut. Itu artinya Ia akan memiliki teman yaitu Puteri Febe Ikan yang sangat baik hati. Kuku Kura-kura dan Muo Ikan pun meminta maaf karena selama ini telah meremehkan Nera. \#moral \#karakter \#mutiaranerakerang \#28

"Terimakasih Peri Mawar, ternyata pergi ke Negeri kejujuran itu menyenangkan," kata Mafi.

Mulai besok aku akan bisa bersepeda ke sekolah, terima kasih Papa-Mama dan juga Peri Mawar yang 
mengajakku pergi ke Negeri efektif demi internalisasi pendidikan Kejujuran," kata Mafi moral dan karakter anak. Sastra anak mengembangkan senyumnya. \#moral yang kaya akan nilai-nilai kehidupan \#karakter \#negerikejujuran \#32

Mencari ilmu dan melewati proses dalam hidup harus senantiasa diperjuangkan. Segala sesuatunya harus diawali dengan kejernihan pikir dan keikhlasan nurani untuk selalu jujur dalam setiap jengkal dan alian napas, demi ilmu yang bermanfaat dan barokah. Sekelumit cerita berjudul Negeri Kejujuran adalah gugusan realitas bangsa Indonesia yang krisis kejujuran. Pemerolehan fasilitas harus betul-betul diminta secara jujur baik kepada orang tua dan negera. Kondisi saat ini, semuanya mampu bermain dan berbohong dengan topeng kejujuran di mana-mana. Cobalah berkontemplasi, masuklah ke ruang terdalam jiwa dan hatimu, lihatlah ada apa di sana. Ketuklah untuk selalu jujur dan semadi di negeri kejujuran bernama hati.

2. Implementasi Sastra Anak sebagai Bahan Ajar di Sekolah Dasar

Bahan ajar sastra anak yang dibuat dengan menarik dan menyenangkan akan menjadi sarana akan menginspirasi kejiwaan anak untuk selalu berprilaku postitif. Perlunya bahan ajar sastra anak menurut pandangan Stewig (1980: 1820) alasan utama mengapa anak perlu bacaan sastra yaitu untuk kesenangan, mengalami petualangan, dapat melarikan diri sejenak dari situasi atau masalah yang dihadapi, menstimulasi imajinasi, memahami diri-sendiri dan orang lain.

Implementasi bahan ajar sastra anak di sekolah dasar akan menjadi bergairah apabila seorang guru mampu mendongeng tentang cerita binatang yang lucu-lucu atau melakukan monolog dengan penjiwaan yang maksimal di depan siswa. Melalui bahan ajar sastra anak, akan mempermudah mencapai proses dan tujuan pembelejaran yang diinginkan. Saat ini, media yang efektif untuk menanamkan ajaran moral dan karakter bisa dimaksimalkan melalui internalisasi sastra anak terhadap anak-anak usia sekolah dasar. Sastra anak sebagai pintu yang menyenangkan untuk 
membuka pintu-pintu yang lain untuk pengetahun segala terutama pendidikan bahasa dan sastra di sekolah dasar.

\section{E. Simpulan dan Saran}

Simpulan penelitian ini tentang ajaran moral dan karakter adalah (1) Moral dan karkter anak sungguh memprihatinkan akhir-akhir ini ketika di mana-mana terjadi pelecehan seksual dan pencabulan, pelaku dan korbannya kebanyakan dari kalangan anak-anak. Hal tersebut dipandang perlu dan penting menyalurkan pengetahuan tentang sastra anak yang kaya ajaran moral dan karakter sudah menjadi keharusan orang tua dan para guru di sekolah dasar untuk kembali dituturkan dan diajarkan. (2) Implementasi bahan ajar sastra anak di sekolah dasar akan menjadi bergairah apabila seorang guru mampu mendongeng tentang cerita binatang yang lucu-lucu atau melakukan monolog dengan penjiwaan yang maksimal di depan siswa. Melalui bahan ajar sastra anak, diyakini mempermudah mencapai proses dan tujuan pembelejaran yang diinginkan. Saat ini, media yang efektif untuk menanamkan ajaran moral dan karakter bisa dimaksimalkan melalui internalisasi sastra anak terhadap anak-anak usia sekolah dasar. Sastra anak sebagai pintu yang menyenangkan untuk membuka pintu-pintu yang lain terkait ilmu pengetahun terutama pendidikan bahasa dan sastra di sekolah dasar.

Saran-saran yang dapat peneliti berikan terhadap seluruh stakeholder untuk terus menerus melakukan proses maksimal dalam rangka memperbaiki moral dan karakter anak bangsa. Menjadikan sastra anak sebagai salah satu bahan ajar dan media untuk berkontribusi memperbaiki moral dan karakter anak bangsa adalah langkah strategis.

\section{DAFTAR PUSTAKA}

Ikhwan, Wahid Khairul. 2013. Upaya Menumbuhkan Karakter Anak dalam Pembelajaran Sastra Anak dengan Model Play-Learning dan Performance-Art Learning di SDN Banyuasin 4. Jurnal Widyagogik. Vol. 1, Januari-Juni 2013.

Koesoema, Doni. 2007. Pendidikan Karakter Strategi Mendidik Anak di Zaman Global. Jakarta: Gasindo.

Kusmarwanti. 2012. Menumbuhkan Karakter Anak Melalui Pemebelajaran Sastra di 
Sekolah Dasar. Makalah disampaikan dalam Seminar Nasional dan Temu Alumni Dies Natalis ke-48 UNY, 5 Mei 2012

Nurgiyantoro, Burhan. 2013. Sastra Anak; Pengantar Pemahaman Dunia Anak. Yogyakarta: Gadjah Mada University Press.

Sarumpaet, Riris K. Toha. 2007. Dengan Sastra Menjadi Manusia. Susastra 5. Jurnal Ilmu Sastra dan Budaya. Vol. 3 No. 5. Tahun 2007.

Stewig, John Warren. 1980. Children and Literature. Chaniago: Rand Mcnally College Publishing Company. 